\title{
The Application of Human Rights Law to Everyday Civilian Life Under Rebel Control
}

\author{
Katharine Fortin ${ }^{1}$
}

Published online: 8 August 2016

(c) The Author(s) 2016. This article is published with open access at Springerlink.com

\begin{abstract}
This article draws upon social science literature to offer a new assessment of the normative value of human rights law vis-à-vis international humanitarian law in territory under armed groups' control. In particular, the article considers how the two bodies of law can be applied in a complementary manner to regulate the everyday life of civilians who are not involved in hostilities. The article demonstrates that while it might be tempting to imagine that concerns relating to rights such as the freedom of movement, the right to work or protection from common crime are completely displaced by considerations of physical security and survival in times of armed conflict, in reality this is often not the case.
\end{abstract}

Keywords Armed groups · Human rights law · Governance · Everyday life

\section{Introduction}

Although it is now commonplace for human rights accountability mechanisms to hold armed groups to account under human rights law, the long-running academic debate about armed groups and human rights law continues. ${ }^{1}$ Firstly, there is debate on the question of whether and when armed groups have obligations under human

\footnotetext{
1 See for example, Report of the Secretary-General's Panel of Experts on Accountability in Sri Lanka, 31 March 2011; Report of the United Nations Fact-Finding Mission on the Gaza Conflict, UN Doc. A/HRC/ 12/48, 23 September 2009; Report of the Independent International Commission of Inquiry on the Syrian Arab Republic, UN Doc. A/HRC/22/59, 5 February 2013 and Preliminary Report of the International Commission of Inquiry on the Central African Republic, UN Doc. S/2014/373, 26 June 2014.
}

Katharine Fortin

K.M.A.Fortin@uu.nl

1 Utrecht University, Utrecht, The Netherlands 
rights law. ${ }^{2}$ Secondly, there is debate about the normative value that human rights law brings to the legal framework of non-international armed conflicts. ${ }^{3}$ The disconnect between law and practice on this issue is troubling and creates an imperative to find clarity on these questions. An equal need for clarity arises from the fact that in many different countries of the world today, civilians are living under the control of armed groups. One only needs to think of high-profile armed groups such as the Islamic State (IS) to appreciate the reality of this. At the height of its power in March 2015, the IS was said to have control over 10 million people living in towns and rural areas in the regions of Syria and Iraq under its control. ${ }^{4}$ At the end of 2014, documentary evidence indicated that IS had at least fourteen government ministries that addressed a wide range of issues such as military and defence, finance and currency, education, health and natural resources. ${ }^{5}$ Documents also indicate that IS has been active in the regulation of a broad range of further issues relating to everyday life, such as fishing, telephone subscriptions, vaccinations, electricity provision, sanitation services and agriculture. ${ }^{6}$ The fact that armed groups like IS are performing governance activities creates a pressing need to understand the relevance of human rights law to the legal framework that regulates their actions.

From a legal perspective, the purpose of this article is not to address how and when it can be legitimately argued that armed groups are bound by human rights law. This author has shown in a forthcoming longer study that a number of respectable legal arguments can be employed to explain how armed groups are bound by human rights law in instances where they control territory. These can be summarised briefly: first, the law of belligerency and insurgency offers a historical precedent for third States holding armed groups to be bound by the obligations of the State, in areas where they take over the functions of government and the de jure government is absent. Additionally, there are indications that armed groups may be bound by certain human rights law, via the human rights obligations of the State by virtue of their control over territory and the default of the de jure government. ${ }^{7}$ Likewise, armed groups can be said to be bound by some (but not all) human rights obligations through rules of customary international law to that effect, as demonstrated by State practice and opinio juris. When armed groups do not control

\footnotetext{
2 For an introduction to the debate on this question, see, inter alia, Rodley (1993), pp. 297-313; Moir (2002), p. 45; Clapham (2006), pp. 271-299; Ryngaert (2008); Constantinides (2010); Rodenhauser (2012).

${ }^{3}$ In particular, it has been argued that human rights norms are almost identical to international humanitarian law norms. See for example, Zegveld (2002), p. 52.

4 S. Nebehay, 'Islamic State controlled parts of Syria, Iraq largely out of reach-Red Cross', 13 March 2015, http://www.reuters.com/article/us-mideast-crisis-syria-icrc-idUSKBN0M921N20150313.

5 Al-Tamimi (2015).

6 Ibid.

7 See for example Art. 9 of the Articles on State Responsibility for Internationally Wrongful Acts. The text of these Articles and Commentaries are found in the Report of the International Law Commission 2001, Fifty-third session, UN General Assembly Official Records, Fifty-Sixth Session, Supplement No. 10, UN Doc. No. A/56/10. For previous discussions of the application of Art. 9 to armed groups see Ruys (2007), pp. 285-290; Ryngaert (2008), p. 361; Sivakumaran (2005), p. 551; McCorquodale and La Forgia (2001), pp. 213-214 and Hessbruegge (2005), pp. 62-63.
} 
territory, the author has found less weighty historical or legal precedents for the idea that armed groups are bound by human rights norms. However, as she has demonstrated in her longer study, a conceptual analysis of the international criminal law on crimes against humanity indicates that armed groups are bound by the corresponding underlying norms of human rights law.

The purpose of this article is to examine the second uncertainty relating to the value of human rights law vis-à-vis international humanitarian law. After all, if, as some academics have argued, the application of human rights norms to armed groups has little normative value vis-à-vis international humanitarian law, it is unclear whether the burgeoning practice of human rights accountability mechanisms is either normatively legitimate or useful. The article addresses this question by drawing upon the recent surge of literature from the social sciences examining the reality of life under rebel control. ${ }^{8}$ One of the most interesting findings in this body of literature is the observation that armed groups engage in governance activities more often that it was often thought. ${ }^{9}$ Another relevant finding is that territory under rebel control is often characterised by a considerable degree of order and organisation. ${ }^{10}$ This observation contradicts previous assumptions that, short of a few exceptions, territory under rebel control is rarely organised. Social science literature also notes that people living in territory under rebel control retain a greater measure of personal agency than is often thought. ${ }^{11}$ This literature from political sciences and anthropology is rarely utilised by lawyers. But, as this article will show, it is an important resource when seeking to evaluate the question of the added value of human rights law vis-à-vis international humanitarian law in territory under rebel control. It demonstrates that while it might be tempting to imagine that rights such as the freedom of movement, the right to work or protection from common crime are displaced by more pressing considerations of physical security and survival in times of armed conflict, in reality this is often not the case.

\section{Armed Groups and Governance}

When applied to armed groups, the term 'governance' has been used to describe how an insurgent group regulates life within a defined territory and provides public services to the civilian population. It has been noted that it is hard to find armed groups who control populated territories that do not establish some form of government structure. ${ }^{12}$ Usually the purpose of an armed group's civilian wing is to enable the group to regulate its relations with the civilian population. Importantly, the concept of 'governance' is generally seen to be a 'more encompassing

\footnotetext{
8 Arjona, Kasfir and Mampilly (2015), p. 1.

9 Kasfir (2015), p. 26.

${ }^{10}$ Kalyvas (2009), p. 71.

11 Arjona, Kasfir and Mampilly (2015), p. 2.

12 Kasfir (2015), p. 26.
} 
phenomenon than government'. ${ }^{13}$ In other words, for political scientists, it is possible to conceive of 'governance' without 'government'. ${ }^{14}$ Mampilly, in his influential study on insurgent governments and civilian life, has observed that governance activities by armed groups cover a range of activities that include the provision of security, public services such as healthcare and education, the protection of food supplies, the provision of housing or land, the resolution of civil disputes, the tackling of social problems such as crime, prostitution, drug abuse or theft and the regulation of the market. ${ }^{15}$ When considering this description, it is clear that there is a significant overlap between the paradigm of 'law enforcement' referred to by lawyers and the concept of 'governance' referred to by social scientists. The law enforcement paradigm, as opposed to the conduct of hostilities paradigm, is a term used by lawyers to describe the factual and legal framework which applies when individuals or territory fall under the control of one party to an armed conflict. While there remains some disagreement on the issue, it is a paradigm which is widely thought to be regulated by international humanitarian law and international human rights law. ${ }^{16}$ The obvious overlap between these two concepts makes it useful for lawyers to consider the literature on governance to find out how armed groups act in territory under their control.

Literature from political sciences on governance demonstrates that there is often a surprising degree of order in territory which falls outside the control of the de jure government. ${ }^{17}$ All too often in armed conflict analysis, territory outside the State's control is assumed to be wracked with Hobbesian chaos. ${ }^{18}$ However, recent findings from social scientists conducting research on conflict zones have repeatedly observed this assumption to be untrue, commenting that 'everyday life' in conflict areas is much more ordered than it is often imagined. Verhoeven recounts how although to outsiders Somalia resembled a 'terrifying war zone', in fact it was a 'complex mosaic of traditional and imaginative informal mechanisms and pacts [which] provided a reasonable degree of stability'. ${ }^{19}$ Indeed, research by political scientists shows that armed actors are often willing to 'eliminate common crime' in areas under their control. ${ }^{20}$ Likewise, armed groups often feel forced to develop and uphold structures for maintaining civilian life. ${ }^{21}$ This literature provides lawyers with the important reminder that armed groups may control territory and undertake law enforcement activities in more circumstances than those contemplated by

\footnotetext{
13 Mampilly (2011), p. 3 citing Rosenau (1992), p. 12.

14 Ibid.

15 Ibid., p. 4.

16 See for example Gill (2013), p. 346. See also Melzer (2009), p. 89.

17 See Kolomba Beck (2012), pp. 123-124. See also Ellsberg (2003), p. 114 as cited by Kalyvas (2009), p. 71.

18 Mampilly (2011), pp. 7, 28, 35 and 40. See also Kalyvas (2009), p. 384.

19 Verhoeven (2009), pp. 411-412 and 414.

${ }^{20}$ Kalyvas (2009), p. 70.

${ }^{21}$ Mampilly (2011), p. 31.
} 
Additional Protocol II. ${ }^{22}$ For example, there may be situations in which an armed group takes control over a town overnight, and overnight finds itself in control of the town's population and already existing prison population. In such instances, an armed group may take immediate steps to control the town's population by instigating curfews, calling public meetings, taking over broadcasting media or setting up checkpoints. ${ }^{23}$ An armed group may also immediately start exerting its authority over the population by punishing alleged collaborators. Similarly, an armed group may also exercise governance over its own combatants and their families. For example, if an armed group adopts a nomadic existence or has been encamped or exiled in a certain geographical location for generations. ${ }^{24}$

This material suggests that armed groups partake in law enforcement activities in different, or more nuanced, ways than is often noted in legal literature. The idea that they do so leads to the connected observation that very few armed groups' governance activities are State-like in character. Indeed, while legal literature tends to present law enforcement activities and territorial control in binary terms (i.e. armed groups are either State-like or non-State-like, territory is either controlled by the State or the armed group, law enforcement activities are either provided by the State or the armed group), research from political scientists shows us that the provision of law enforcement activities by armed groups is a complex phenomenon that is hard to categorise in absolute terms. For example, it is often commented in legal literature that the Liberation Tigers of Tamil Eelam (LTTE) in Sri Lanka had a sophisticated legal system comprising of a complex network of police stations, district courts and appeal courts. ${ }^{25}$ However, legal literature does not point out the nuance that the LTTE never provided health or education services in the territory under its control. ${ }^{26}$ Interestingly, these issues remained the responsibility of the Sri

\footnotetext{
22 Art. 1 of Additional Protocol to the Geneva Conventions of 12 August 1949, and relating to the protection of victims of non-international armed conflicts, 8 June 1977 (Additional Protocol II), applies to non-international armed conflicts which take place in a territory of a High Contracting Party between its armed forces and dissident armed forces or other organised armed groups, which, under responsible command, exercise such control over a part of its territory as to enable them to carry out sustained and concerted military operations and to implement the Protocol.

23 An example of a rebel group controlling a town for a short period in this manner was seen with the M23 rebel group's control of Goma in 2013. For relevant news stories see: 'DR Congo rebels impose unacceptable curfew, UN', i24 News, 4 September 2013, http://www.i24news.tv/en/news/international/ africa/130905-dr-congo-rebels-impose-unacceptable-curfew-un; D. Blair, 'Goma falls to M23 rebels without expected bloodbath', The Telegraph, 20 November 2012, http://www.telegraph.co.uk/news/ worldnews/africaandindianocean/democraticrepublicofcongo/9691489/Goma-falls-to-Congos-M23-rebelswithout-expected-bloodbath.html. See also the public rally convened by M23 after it took Goma. D. Blair, 'Congo's rebel army vows to take control of all DR Congo', The Telegraph, 21 November 2012, http:// www.telegraph.co.uk/news/worldnews/africaandindianocean/democraticrepublicofcongo/9693043/ Congos-rebel-army-vows-to-take-control-of-all-DR-Congo.html; Reporters without Borders, 'TV Stations Silenced by M23 Resume Retransmitting in Goma', 4 December 2012, http://en.rsf.org/drc-concernabout-m23-s-news-control-21-11-2012,43706.html; Human Rights Watch, 'M23 rebels Rape, Kill Civilians', 22 July 2013, http://www.hrw.org/news/2013/07/22/dr-congo-m23-rebels-kill-rape-civilians.

24 See the study of the National Union for the Total Independence of Angola (UNITA) in Angola by Kolomba Beck where she recalls how UNITA families were micro-managed by the armed group in bush encampments. Kolomba Beck (2012), pp. 113-117.

25 See for example Sivakumaran (2009), p. 494.

26 Mampilly (2011), pp. 110-111.
} 
Lankan State for the duration of the conflict. ${ }^{27}$ Political science literature repeatedly demonstrates that governance structures in areas under rebel control are often more complex than it is often thought, with input from, and alliances between, multiple players including armed groups, non-governmental organisations (NGOs), religious leaders and the State. ${ }^{28}$ In a similar vein, although the Forces Nouvelles in the Ivory Coast had a large prison population under its control for the duration of the period that it controlled the north of the country, the group did not run a justice system because the judiciary had fled to the South of the country at the start of the conflict. $^{29}$ Again this example shows that an armed group's decision to provide public services often responds to a complex set of country-specific factors. These factors can range from the prior provision of services by the State, the expectations of the civilian population and brokered agreements between the armed group and the State. ${ }^{30}$

Continuing along this theme, political science literature also makes clear that armed groups do not only perform governance activities as part of their battle for legitimacy against the incumbent government. ${ }^{31}$ While in many instances this may be true, armed groups often provide public services for a variety of different reasons. Interestingly, as has already been mentioned, armed groups sometimes feel compelled to provide governance activities. Mampilly notes in his research on the Democratic Republic of the Congo (DRC) that the vice president of the Rally for Congolese Democracy-Goma (RCD-Goma) considered the group to be under an obligation to set up what was 'more or less a government' as a consequence of the control it exerted over the territory. ${ }^{32}$ A similar view was expressed by the LTTE's chief negotiator, Mr Anton Balasingham who stated that the group's law enforcement apparatus was a 'necessity' for a group exercising control over such a large area. He stated:

We explained that these courts and police stations have been functional for the last 12 years and that the ground reality is that as a consequence of this war the

\footnotetext{
27 Ibid.

28 See for example Barter (2015) on the governance alliances formed between the Free Aceh Movement, rural Islamic teachers and student activists. See also Arjona (2015) on the concept of 'aliocracy', i.e. the provision of governance by other actors in addition to armed groups, p. 182.

29 D. Balint-Kurti, 'Cote D'Ivoire's Forces Nouvelles, Chatham House', September 2007 Africa Programme Armed Non-State Actors Series, p. 26. See also Eighteenth Progress Report of the SecretaryGeneral on the United Nations Operation in Côte d'Ivoire, UN Doc. No. S/2008/645 and Twenty-fourth report of the Secretary-General on the United Nations Operation in Côte d'Ivoire, UN Doc. No. S/2010/ 245 on the restoration of the judiciary and parallel system of administration maintained by the Forces Nouvelles.

30 See Weinstein (2007) who argues that an armed group with an income stream from abroad or natural resources will be less reliant upon the civilian population for survival and therefore will be less likely to create a form of governance that encourages support from the civilian population. See also Mampilly who argues that the nature of the pre-conflict relationship between State and society, particularly in the area of service provision, will shape the rebel command's preferences for civilian governance. Mampilly (2011), p. 234. See also Kalyvas (2009).

31 Kilcullen (2010), pp. 147-149 sets out that armed groups often adopt governance roles as part of a battle for legitimacy.

32 Mampilly (2011), p. 190.
} 
LTTE has established control over $70 \%$ of the area in the northeast. There are huge populations here and we have to administer them and for the purposes of maintaining law and order, or rather social order and cohesion we need to have certain institutions. [...] [T] hese police stations are necessary instruments to maintain law and order because we cannot allow anarchy and social disorder in areas controlled by us. ${ }^{33}$

Similar statements have come from officials of the Islamic courts operating in Syria, under rebel-controlled territory. Marwan Gayad, a former appeals court judge who defected from the Syrian government and was serving as the general prosecutor for the United courts Council at the time of his interview in 2012 said 'we created this temporary judicial council as an emergency solution, like when a doctor removes a bullet from a patient without using an anaesthetic'. ${ }^{34}$

\section{The Relevance of Literature on Governance to the Legal Framework}

From a legal perspective, the first point to note is that the literature on governance from political science literature confirms that the law enforcement paradigm is important in territory under rebel control. It confirms that armed groups exercise authority over persons or territory, take steps to maintain public order and take measures to suppress crime or other subversive activities. Importantly, it also confirms that there is an important role for human rights law, alongside international humanitarian law within this paradigm. Most significantly the literature from political scientists and anthropologists on armed conflict confirm a view that there are significant aspects of people's lives which are not explicitly connected to the armed conflict. This literature puts forward the idea that everyday life goes on in times of armed conflict much more regularly than it is often observed. In a longer study on the topic of armed groups and human rights law, the present author has labelled this phenomenon the 'life goes on driver'. The use of the word 'driver' is intended to capture the idea that the phenomenon of everyday life is a force with an irrepressible momentum that is partly defined by the armed conflict, but partly exists outside of the armed conflict in the population itself. In many ways, the 'life goes on driver' is the other side of the governance 'coin'. It has been shown above that governance structures are often instituted in response to life going on in territory under rebel control, but they also constitute important tools which facilitate and enable life to carry on. In that sense, the 'life goes on driver' and the provision of governance activities by an armed group can be seen as two interdependent and mutually reinforcing phenomena impacting upon the legal landscape.

\footnotetext{
33 'LTTE police stations "not a new phenomena"_Balasingham', TamilNet, 3 December 2002, http:// www.tamilnet.com/art.html?catid=13\&artid=7932. A similar sentiment was stated by the vice president of RCD-Goma in 1998 when it took control in the Kivus. He said: 'We hadn't realized that we would have to set up what is more or less a government so fast, but it's an obligation now', BBC Monitoring 1998, as cited by Mampilly (2011), p. 190.

34 I. Watson and R. Razek, 'Rebel court fills void amid Syrian civil war', 26 January 2012, http://edition. cnn.com/2013/01/25/world/meast/syria-rebel-court/.
} 
Indeed, it is increasingly noted in research emerging from political sciences and anthropology that the experience of everyday life in times of armed conflict has been all too often excluded from empirical research. Instead, there has been a general tendency for an analysis of non-international armed conflicts to be conducted in a top-down manner, focusing mainly on the identification of the parties and their motivations. ${ }^{35}$ As a result, the dominant accounts of armed conflict have tended to focus on how individuals living in their midst cope with violence as victims. ${ }^{36}$ In order to redress this balance, a growing body of researchers have taken what has been termed a 'micropolitical' approach to armed conflict, which focuses on the social dynamics of daily life. ${ }^{37} \mathrm{~A}$ micropolitical approach concentrates on how individuals and groups utilise formal and informal power structures in order to achieve their goals within organisations. The research that has emerged from this bottom-up approach has radically challenged dominant narratives of armed conflict and adjusted the image of the individual's role within it. One of the key observations emerging from micropolitical studies is the idea that individuals retain a large degree of agency in the midst of armed conflict. In social science literature, the term 'agency' refers to an individual's ability to act independently and to make free choices. $^{38}$

The idea that civilians retain a large measure of agency in times of armed conflict challenges the widespread perception that violence is the only concern of individuals living in a war zone. It also challenges the dominant narrative of armed conflict, under which rather than retaining their status as 'brothers, workers, neighbours and elders', individuals are distilled down to reductionist categories such as "refugees", whose only recognizable role is to flee violence, or as "combatants" whose only analysed role is to perpetrate violence, or as "victims", whose only role of relevance is to suffer violence'. ${ }^{39}$ Indeed, it is noteworthy that researchers who take a micropolitical approach repeatedly emphasise that civilians are rarely only victims. ${ }^{40}$ Instead, individuals continue pursuing life goals in the midst of the armed conflict and build life narratives which may be partly defined by the armed conflict, but which are often also partly independent of the armed conflict. ${ }^{41}$ In other words, emerging empirical research challenges the exclusivity of what has been called 'state of emergency' thinking in armed conflict, demonstrating a counter image of everyday life persisting in the midst of that crisis. ${ }^{42}$ It is important to note that by identifying the durability of everyday life in the midst of armed conflict, researchers

\footnotetext{
35 Kalyvas (2009), p. 39.

36 Lubkemann (2010), pp. 11-12 and 21 and Mampilly (2011), p. 6.

37 Kolomba-Beck (2012), pp. 16 and 23 where she defines 'micropolitical studies' as those which aim to 'understand and theoretically construct social processes in wars based on an inquiry into micro-level dynamics'.

38 Kalyvas (2009), p. 71 and Mampilly (2011), p. 67.

39 Lubkemann (2010), p. 12.

40 Ibid. and Mampilly (2011), p. 67.

41 Kalyvas (2009), p. 390.

42 Kolomba Beck (2012), p. 11.
} 
do not have the intention of downplaying civilians' suffering. Instead, their intention is to highlight the 'dignity preserved by people who live through war situations'. 43

The life goes on phenomenon identified above is particularly important in protracted armed conflicts where that conflict becomes the normal backdrop of daily life. ${ }^{44}$ Here, common crimes will often continue, people will get married, children will be born, couples will divorce and people will die. ${ }^{45}$ Wherever possible children will continue going to school or receiving an education, people will carry on going to work and taking their goods to market. People will carry on borrowing money, having disputes with their neighbours, buying and selling commodities and travelling around the country to the extent to which it is possible. Indeed, empirical research indicates that the 'life goes on driver' is just as much a force to be reckoned with in territory controlled by armed groups, as in territory controlled by the State. ${ }^{46}$ It has been commented in this respect that in times of non-international armed conflict, 'most people most of the time are interacting in non-violent ways'. ${ }^{47}$ As a result, just as social sciences literature shows that territory under rebel control is usually not as chaotic as it is often thought, it also shows that everyday life under rebel control is more complicated than simply victimhood and violence.

\section{The Life Goes on Driver and Human Rights Law}

From a legal perspective, the adjustment of the armed conflict narrative confirms that individual rights remain significantly important in territory controlled by armed groups. In the climate of fear and suspicion which often accompanies a noninternational armed conflict, there will be a more pressing imperative than ever to protect the family unit, privacy, the home and correspondence. Far-reaching curfews or checkpoints may not only prevent people from moving around but also prevent them getting to work, transporting their goods or working their land. Children may be prevented from attending school. Radio and television stations may be prevented from broadcasting freely, in a manner that constitutes an interference of the right to freedom of expression. Likewise, people may be prevented from attending or convening public rallies, in a manner that interferes

\footnotetext{
43 Ibid., p. 147.

44 'Bombardments can't stop the Disco beat in Aleppo', Malay Mail Online, 23 November 2014, http:// m.themalaymailonline.com/features/article/bombardments-cant-stop-the-disco-beat-in-aleppo.

45 Commenting on how in the 'throes of war' Mozambicans 'still lived everyday lives, remained social beings, and pursued key life projects, such as marrying and bearing children', Lubkemann recalls the words of an artist in Mozambique when she recalls meeting a pregnant friend in the middle of the armed conflict: '[A]lthough the bloodshed was all around then, you could still find some lovers. They would say all is gone, but let's at least love one another to create the future [...]. I was joking around one day with a friend as I often do. I saw she was pregnant and said "You're pregnant, but we are in the middle of a war!" And my friend responded, "Yes, it is war, but even here on the street we still make love".' Lubkemann (2010), p. 217.

46 C. Reuter, 'Daily Life in Aleppo: The Struggle for Normality amid the Ruins of War', Spiegel Online, 26 February 2013, http://www.spiegel.de/international/world/the-struggle-to-maintain-order-in-rebelcontrolled-aleppo-in-syria-a-885396.html.

47 Mampilly (2011), p. 7 citing Tilly (2003), p. 12.
} 
with their right to freedom of association. People may become more susceptible to abuse by private corporations or employers seeking to exploit the situation of armed conflict, to impose harsher conditions of work or employment. Common or violent crime may increase as a result of people living in poverty, suffering trauma from the conflict or taking advantage of reduced policing. Conversely, authorities may institute an over-zealous response to common crime that results in arbitrary detentions, corporal punishment, violations of the right to a fair trial or violations of the right to life.

It is important to note that many of these issues are not regulated by international humanitarian law at all or are only minimally dealt with. The reason for this is that, typically, these are issues which do not relate exclusively to armed conflict. They are relevant in both times of armed conflict and peace. Notably, only human rights law can protect people's ability to work, move around freely, access healthcare, freely express an opinion, gather in public places and live in an environment free from common crime. ${ }^{48}$ Significantly, only human rights law contains the right to freedom of expression and the right to freedom of association. ${ }^{49}$ Human rights law also contains important provisions on the right to work, the right to just and favourable conditions of work and the right to an adequate standard of living, including adequate food, clothing and housing. ${ }^{50}$ In a similar vein, only human rights law contains provisions relating to people's right to marry freely and a child's right to be registered at birth. ${ }^{51}$ Human rights law also contains many important and detailed provisions relating to the rights of women, including their right not to be discriminated against in society. ${ }^{52}$ The fact that these are issues which are dealt with predominantly by human rights law serves in part to confirm the conceptual parameters of international human rights law and international humanitarian law which will be set out below. These are key rights which are necessary to protect people's everyday life from unnecessary interference, and they are all issues addressed principally by human rights law, rather than international humanitarian law.

\section{The Life Goes on Driver and Human Rights Law vis-à-vis International Humanitarian Law}

The identification of the 'life goes on driver' also leads to a related observation that where both bodies of law deal with similar factual issues, human rights norms and international humanitarian law norms are in many cases additive. They create

\footnotetext{
48 See Art. 6 of the International Covenant on Economic, Social and Cultural Rights (ICESCR) which entered into force on 3 January 1976; Art. 12 of the International Covenant on Civil and Political Rights (ICCPR) which entered into force on 23 March 1976; Art. 12 ICESCR; Art. 19 of the ICCPR; Art. 21 of the ICCPR and, inter alia, the positive obligations which accompany Arts. 6 and 7 of the ICCPR.

49 See Arts. 19 and 21 of the ICCPR.

50 See Art. 6 and Art. 11 of the ICESCR.

51 See Art. 23(3) and Art. 24(2) of the ICCPR.

52 See Art. 26 of the ICCPR and the Convention on the Elimination of all Forms of Discrimination against Women.
} 
a net normative gain, whether they apply simultaneously or alternatively. In instances where the two bodies of law apply simultaneously to the same issue, they often approach the issue from a slightly different perspective, meaning that they contribute to the net value of protection and a single individual can benefit from both bodies of law simultaneously. For example, while international humanitarian law prohibits parties to an armed conflict from moving people from one place to another against their will, human rights law secures their freedom of movement to move around freely. ${ }^{53}$ Likewise, while international humanitarian law secures medical assistance for the 'wounded' and 'sick', it does not oblige parties to an armed conflict to provide more generalised medical care to persons who are not sick. ${ }^{54}$ However, human rights law contains a provision on the right to health, in the sense of a positive right that addresses medical needs which are independent from the armed conflict as such, and extends to healthy people as well as those who are already sick. Such an independent right is particularly important for people seeking vaccinations or medical services related to nutrition, family planning or hygiene. ${ }^{55}$

The adjustment of the armed conflict narrative is also helpful when considering how the dividing line should be drawn between the two bodies of law on the few issues on which international humanitarian law and international human rights law provide alternative protection in the legal framework, e.g. when the two bodies of law provide slightly different protections in relation to a single broadly defined matter. In these instances, the two bodies of law will be 'alternative' in that a single individual will generally fall within either one regime or the other, at any given moment, but not both. An example of the two regimes existing in an alternative fashion is seen in issues relating to detention. ${ }^{56}$ Here, it has been frequently commented that international humanitarian law and international human rights law provide different regimes of protection. International humanitarian law protections are found in common Article 3 of the Geneva Conventions and Articles 5 and 6 of Additional Protocol II. While these provisions provide important protections relating to the conditions in which a person is kept in detention, they fail to contain any procedural guarantees preventing arbitrary detention. International human rights law, on the other hand, provides more detail on procedural matters, in addition to laying down standards of treatment. Most noteworthy, international human rights law requires that each instance of detention has a legal basis. For some, the

\footnotetext{
53 Compare for example Art. 17 of Additional Protocol II prohibiting the forced movement of civilians with Art. 12 of the ICCPR.

54 Compare for example Art. 7 of Additional Protocol II granting protection for individuals who are sick and wounded with Art. 12 of the ICESCR.

55 Ibid.

56 Another example is found in the rules on the use of force. Here there is debate about whether international humanitarian law or human rights law will govern the use of lethal force against an isolated individual, far from the active hostilities, whose status would allow him or her to be targeted in the conduct of hostilities paradigm. See for example Sassòli and Olson (2008) for an examination of the legal framework relating to killing and detention in non-international armed conflict.
} 
shortcomings of international humanitarian law on detention issues can be overcome by resorting to international human rights law. ${ }^{57}$

Even though it may be possible to fill gaps in the international humanitarian law framework on detention with human rights law norms, there remain key reasons why it is important to know whether a person in detention falls primarily under international humanitarian law or international human rights law. Firstly, it is important for International Committee of the Red Cross (ICRC) delegates to know whether a detainee falls under international humanitarian law, as it is the basis of their visitation mandate. ${ }^{58}$ Secondly, it is important to know which regime a person falls under if he or she is mistreated in detention, because it will be the determining factor of whether a particular act of mistreatment constitutes a war crime. ${ }^{59} \mathrm{~A}$ violation will only constitute a 'war crime' if the person is protected by international humanitarian law. The same can be said when it comes to fair trial rights. Here, although it is often commented that common Article 3 of the Geneva Conventions and Article 6 of Additional Protocol II can be read in a complementary fashion with Article 14 of the ICCPR, it remains important to know whether a person who is prosecuted falls primarily under international humanitarian law or international human rights law. ${ }^{60}$ If he or she falls under international humanitarian law, a violation of his or her fair trial provisions may constitute a war crime under international criminal law. ${ }^{61}$

So far, the question of whether individuals fall within the international humanitarian law or international human rights law framework on issues on which the two bodies of law provide alternative protection has been mainly discussed in relation to individuals associated with armed groups, by either taking on the role of a fighter or directly participating in hostilities. ${ }^{62}$ Yet there has been less attention given to the question of which legal norm should apply to civilians who have no connection to the hostilities. It is shown below that the identification of the idea that everyday life continues in rebel-held territory is important when determining how international humanitarian law and international human rights law work together within the law enforcement paradigm to protect these kinds of civilians. The reason for this is that there are strong legal arguments to be made that the everyday life of civilians which has no nexus to the armed conflict is not governed by international humanitarian law. The fact that international humanitarian law only applies to issues

\footnotetext{
57 Henckaerts and Doswald-Beck (2005), pp. 347-352. See also Casalin (2011), p. 746. It has been pointed out by some academics that human rights law norms on detention are ill-suited to the factual dynamics of a non-international armed conflict. See for example, Sassòli and Olson (2008), p. 622.

58 Tuck (2011), p. 773 and Aeschlimann (2005), p. 88. Both of these authors comment on the fact that while the mandate of the ICRC to visit detainees is derived from international humanitarian law, in practice the ICRC is often led 'by extension to concern itself' with persons deprived of their liberty for reasons unrelated to the armed conflict.

59 See statement by Prosecutor v. Boškoski and Tarčulovski, Case No. IT-04-82-T, Judgment, 10 July 2008 (Boškoski Trial Chamber Judgment), para. 293.

60 Sivakumaran (2014), pp. 490-491 on the application of the lex specialis criteria and the potential for human rights law to flesh out fair trial rights in international humanitarian law.

61 See Art. 8(2)(c)(iv) of the Rome Statute.

62 See for example Hill-Cawthorne (2015); Sassòli and Olson (2008); Sassòli (2011), p. 85.
} 
with a nexus to the armed conflict is not immediately clear from the wording of common Article 3 but has been articulated explicitly by the International Criminal Tribunal for the former Yugoslavia (ICTY) and the International Criminal Tribunal for Rwanda (ICTR), in decisions relating to jurisdiction. For example, already in the Tadić Jurisdiction Decision, the Appeals Chamber asserted that although international humanitarian law applies to the whole country, it does not apply to every act of violence or instance of detention. ${ }^{63}$ The need for incidents to have a nexus to the armed conflict was also confirmed by the ICTR Appeals Chamber in the Akayesu case which stated 'common Article 3 requires a close nexus between violations and the armed conflict'. ${ }^{64}$

Indeed, a study of Additional Protocol II shows that the text supports the idea that international humanitarian law norms which form part of the law enforcement paradigm will only apply to issues with a nexus to the armed conflict. For example, Article 2, paragraph 1 of Additional Protocol II states that:

[t]his Protocol shall be applied [...] to all persons affected by an armed conflict defined in Article 1.

Likewise, paragraph 2 of the same article states:

[a]t the end of the armed conflict, all the persons who have been deprived of their liberty or whose liberty has been restricted for reasons related to such conflict, as well as those deprived of their liberty or whose liberty has been restricted for reasons related to such conflict, as well as those deprived of their liberty or whose liberty is restricted after the conflict for the same reasons, shall enjoy the protection of Articles 5 and 6 until the end of such deprivation or restriction of liberty.

Likewise, Articles 5 and 6 of Additional Protocol II relating to detention and prosecution state that they apply to "persons deprived of their liberty for reasons related to the armed conflict' and the 'prosecution of criminal offences related to the armed conflict [emphasis added]'. The words 'related to the armed conflict' confirm the idea that while international humanitarian law applies to the whole country in a spatial sense, it does not apply operationally to every issue.

The records of the Geneva Conference which produced Additional Protocol II demonstrate that its drafters had a strong desire to limit the scope of Additional Protocol II to issues connected to the armed conflict. They recognised that even in a non-international armed conflict reaching the threshold of Additional Protocol II, there might be significant areas of the country and segments of the population who were not affected by the armed conflict. ${ }^{65}$ This realisation prompted a long

\footnotetext{
63 Prosecutor v. Tadić, Case No. IT-94-1-AR72, Decision on the Defence Motion for Interlocutory Appeal on Jurisdiction, 2 October 1995 (Tadić Jurisdiction Decision), para. 69. See also Prosecutor v. Delalić, Mucić, Delić and Landžo, Case No. IT-96-21-T, Trial Judgement, 16 November 1998, para. 193: 'It is axiomatic that not every serious crime committed during the armed conflict in Bosnia and Herzegovina can be regarded as a violation of international humanitarian law. There must be an obvious link between the crime and the armed conflict'.

64 Prosecutor v. Akayesu, Case No. ICTR-96-4-T, Judgment, 2 September 1998, para. 444.

65 See ICRC (1987), p. 1360, para. 4490.
} 
discussion by the Protocols' drafters about whether the scope of Additional Protocol II should be limited by geography, i.e. should only apply to part of the country. ${ }^{66}$ Eventually, however, the drafters of the Additional Protocol came to the conclusion that it would be more prudent to limit the Protocol's application by 'people' rather than by 'place'. ${ }^{67}$ Hence they confirmed that while the protocol's provisions apply in principle to the whole country, they are limited in effect to people 'affected by an armed conflict'. Importantly, the inclusion of the phrase 'affected by an armed conflict' in Article 2 also has the effect of limiting the scope of Article 4 of Additional Protocol II (fundamental guarantees) to persons affected by the armed conflict. This observation is consistent with the observation above that common Article 3 only applies to issues with a nexus to the armed conflict. It is also consistent with the observation that Article 75 (fundamental guarantees) of Additional Protocol I, which is widely seen as a customary international law provision applying in non-international armed conflicts, also only applies to issues with a nexus to the armed conflict. ${ }^{68}$

The chapeau of Article 75 of Additional Protocol I states that persons will benefit from the protections of the article 'in so far as they are affected by a similar situation referred to in Article 1'. ${ }^{69}$ The commentary to Article 75 of Additional Protocol I provides an explanation for the inclusion of these words as follows:

In general those who contravene the normal laws of the State (ordinary criminals) and who are punished on these grounds, are not 'affected' within the meaning of this article. On the other hand, if security measures are taken against certain individuals because of their attitude, whether true or alleged, with regard to the conflict, Article 75 certainly applies to them. ${ }^{70}$

In other words, the commentary advocates a narrow definition of the term 'affected by the armed conflict' which excludes persons who are in the power of a party to the armed conflict because they have broken the ordinary criminal law.

\footnotetext{
${ }^{66}$ Interestingly, this discussion was along similar lines to the reasoning later found in the Tadić Jurisdiction decision. Tadić Jurisdiction Decision, paras. 66-70.

67 See also Official Records of the Diplomatic Conference on the Reaffirmation and Development of International Humanitarian Law Applicable in Armed Conflicts, Geneva (1974077) Vol. VIII, CDDH/I/ SR.22, p. 211, para. 43 where Mrs Bujard of the ICRC is recorded as explaining that there had been a long discussion of whether the application of the Additional Protocol should be geographically limited at the Conference of Government Experts, but the experts had pointed out that in a large, federal State, for example, it might be better if the Protocol should apply to persons affected by an armed conflict rather than to the territory where the armed conflict took place. To meet that wish, in its draft the ICRC had not included an article concerning the territorial scope of the Protocol.
}

68 See Henckaerts and Doswald Beck (2005), pp. 299-384.

69 The commentary to Art. 75 clarifies that the term 'affected by' means 'touched by or concerned'. Recognising that to a certain extent 'all those who find themselves in the territory of [...] countries at war' are affected 'in some way or another', it also states that such an expansive definition of the term was probably not what was meant by the provision. Instead, it advocates that a narrow approach should be taken to the phrase. It justifies its view on this by pointing to the phrase 'in so far', and saying that it suggests that there will be some people in the country who will not be affected by the armed conflict in the sense of the article. ICRC (1987), para. 3011.

70 Ibid. 
Piecing the above analysis together, it can be seen that the requirement under international humanitarian law that issues should have a 'relationship' with the armed conflict constitutes an important fault line that runs through the law enforcement paradigm. Indeed, in many cases, it helps to identify the dividing line between the conceptual coverage of international humanitarian law, on the one hand, and international human rights law on the other. Significantly, commenting on the scope of Article 75 of Additional Protocol I, Meron observed that its narrow scope reflected the fact that its drafters did not intend to 'revise the entire range of human rights that would otherwise apply between a government and its people'. ${ }^{71}$ In other words, he commented that Article 75 was supposed to complement similar human rights provisions which would continue to apply regardless of the armed conflict. In a similar vein, Bothe, in his authoritative commentary to the Additional Protocols, confirmed that 'the purpose of the Conference was not to draft a Convention on Human Rights'. ${ }^{72}$ The fact that both authors distinguished international humanitarian law from international human rights law confirms a view that international humanitarian law is generally the lex specialis for issues which relate specifically to the armed conflict. ${ }^{73}$

\section{The Nexus Requirement in International Criminal Law as Guidance}

Assistance on where the dividing line in the law enforcement framework is placed can be found in the ICTY's case law on the 'nexus' requirement. The nexus requirement in international criminal law has not been developed to determine whether a particular incident is governed by international humanitarian law or not. Instead, it has been developed to determine whether a particular incident is a 'war' crime or domestic crime. The Boskoški Trial Chamber stated that:

The nexus requirement serves to distinguish war crimes from purely domestic crimes and also prevents purely random or isolated criminal occurrences from being characterised as war crimes. ${ }^{74}$

However, logically, in order to assess whether a particular act can be a war crime, the first question that must be answered is whether the crime is a violation of international humanitarian law. As a result, in developing the nexus test, trial chambers have implicitly articulated a view on the circumstances in which the laws of war will apply. In doing so, they have confirmed that international humanitarian law applies to incidents which are 'substantially related' to the theatre of armed conflict. $^{75}$ They have also confirmed that the location of a particular incident is not

\footnotetext{
71 Meron (1983), p. 596.

72 Bothe et al. (1982), p. 460 as cited by Meron (1983), p. 597.

73 See Legality of the Threat of Use of Nuclear Weapons, Advisory Opinion of 8 July 1996, ICJ Reports 1996, p. 226, at para. 25.

74 Boškoski Trial Chamber Judgment, para. 293.

75 Prosecutor v. Kunarac, et al., Case No. IT-96-23-A, 23/1-A, Appeals Judgment, 12 June 2002 (Kunarac Appeals Judgment), para. 57.
} 
determinative of whether something is able to fall under international humanitarian law or whether a particular incident is a war crime. Instead, it is more important to determine whether the incident was 'closely related to the hostilities occurring in the other parts of the territories'. ${ }^{76}$

\section{The Nexus Requirement}

The finding that there needs to be a close nexus or close relationship between the incident and the armed conflict prompts a reflection on what this means in practice. The Kunarac Appeals Judgment examined the nexus requirement in some detail and provided the following guidance, stating:

The existence of an armed conflict must, at a minimum, have played a substantial part in the perpetrators' ability to commit [the crime], his decision to commit [the crime], the manner in which it was committed or the purpose for which it was committed. ${ }^{77}$

In other words, according to the Appeals Chamber, the nexus requirement would be satisfied if it could be proved that an individual acted under the 'guise of the armed conflict' ${ }^{78}$ While these initial comments seem to define the nexus concept widely, the Appeals Chamber continued by identifying a number of indicators which suggest that a particular crime constitutes a 'war crime', rather than a domestic crime. These include:

The fact that the perpetrator is a combatant; the fact that the victim is a noncombatant; the fact that the victim is a member of the opposing party; the fact that the act may be said to serve the ultimate goal of the military campaign; and the fact that the crime is committed as part of or in the context of the perpetrator's official duties. $^{79}$

These concrete factors suggest that the Appeal Chamber's criteria are in reality rather more stringent. They indicate that the nexus test requires more than the perpetrator simply took advantage of the breakdown of law and order that may accompany an armed conflict. Instead, the nexus test seems to pivot on the role of the perpetrator and the victim, their respective statuses under international humanitarian law and the relationship of the highlighted act with the military campaign of the party to which the perpetrator belongs. The correctness of this narrower approach has subsequently been confirmed by the ICTR Appeals Chamber. ${ }^{80}$

\footnotetext{
76 Ibid., para. 60.

77 Kunarac Appeals Judgment, para. 59. See van der Wilt (2012) for a thorough review of the case law from international criminal tribunals and Dutch courts on the 'nexus requirement'.

78 Ibid., para. 58.

79 Ibid., para. 59.

${ }^{80}$ See Prosecutor v. Rutagana, Case No. ICTR-96-3-A, Appeals Judgment, 26 May 2003, para. 570. See Gagglioli (2014), pp. 513-517 for a discussion of the nexus requirement in international humanitarian law and international criminal law.
} 


\section{The Nexus Requirement as a Dividing Line between International Humanitarian Law and International Human Rights Law}

Framed in these terms, it can be seen that in State-held territory, civilians arrested and prosecuted for reasons connected to the armed conflict will generally fall under the scope of international humanitarian law. In contrast, human rights law will have a key role to play in providing protection to persons subject to the ordinary criminal justice system. With respect to common crime, rights such as the right to life, the right to freedom from arbitrary detention and the right to a fair trial will come to the fore, protecting people accused of crimes without a connection to the armed conflict (i.e. 'ordinary criminals') at every stage of the criminal justice system. ${ }^{81}$ They apply to the acts of law enforcement officers as they patrol the streets, govern the employment of lethal force against individuals with no role in the conflict, the manner and circumstances in which law enforcement officers arrest and detain people and the manner in which individuals are prosecuted on criminal charges. ${ }^{82}$ Likewise, human rights norms play an important role in the promulgation and enforcement of criminal laws that protect individuals from violence by private actors. For example, human rights law requires a State to have an effective legislative framework for prosecuting common crimes. ${ }^{83}$ It also requires a State to ensure that the legislative framework is enforced through the investigation and prosecution of perpetrators and the provision of redress to victims. ${ }^{84}$ While positive obligations exist in international humanitarian law too, they do not extend to the prevention of common crime unless it has a 'clear nexus' to the armed conflict. ${ }^{85}$

However, while the above demarcation between international human rights law and international humanitarian law has clear merit in territory controlled by States, it must be questioned whether it should be applied in the same manner in territory under the control of rebel groups. After all, it is reasonable that an individual arrested in the capital city for murdering his adulterous partner should not be accused of a violation of international humanitarian law. Clearly, such an individual should fall under the provisions of the ordinary criminal law and be protected by the human rights law norms above that protect people accused of common crime. Likewise, if there is a violation of the individual's rights in the process of that individual's arrest or trial, it is reasonable that this violation is treated as a human

\footnotetext{
81 See the commentary to Art. 75 of Additional Protocol I cited above at footnote 69.

82 See in particular the right to life, the right not to be arbitrarily detained and the right to a fair trial.

83 See for example, Nachova and others v. Bulgaria (Application No. 43577/98 and 43579/98), Judgment, 6 July 2005, para. 96.

84 Ibid.

85 Indeed, Art. 1 of the Geneva Conventions 1949 contains the same 'respect and ensure respect' wording, from which the legal basis of some of the earliest articulations of 'due diligence' obligations in human rights law have emerged. See Velasquez Rodriguez case, Inter-American Court of Human Right, Judgment, 29 July 1988, paras. 165-172. Adopting the same reasoning as the Inter-American Court in the international humanitarian law framework, the words 'ensure respect' in Art. 1 of the Geneva Conventions can be argued to place an obligation on both parties to a non-international armed conflict to prevent private individuals violating common Art. 3 and Additional Protocol II.
} 
rights violation, rather than a war crime. But in territory under rebel control, the position is less straightforward because an application of the wider Kunarac approach leaves room for a variety of responses. For example, should one say that all incidents that involve an interaction between the rebel group and the civilian population have a 'nexus' to the population? ${ }^{86}$ After all, the power asserted by an armed group vis-à-vis the individual has been acquired as a result of the hostilities. As a result, in some senses, an armed group is always acting under the 'guise of the armed conflict' in its relations with civilians because its position of authority is derived from the armed conflict.

To some, the main advantage of casting the conceptual net of international humanitarian law widely is that international humanitarian law ends up as the exclusive legal framework in the law enforcement paradigm when applied to armed groups. ${ }^{87}$ This approach avoids the need to address armed groups under human rights law at all, which, for scholars doubting the legitimacy of this practice, may be an advantage. But such an approach has some important drawbacks. First, it risks diluting the specificity of international humanitarian law as a regime that is designed to regulate actions related to the armed conflict. Indeed, taken to an extreme level where everything that occurs within rebel territory is deemed to have a nexus to the armed conflict, it could lead to the situation that many 'private' crimes taking place in territory controlled by an armed group are categorised as 'war crimes'. Most importantly, such an approach also ignores the explicit wording of Article 5 and Article 6 of Additional Protocol II which seems to acknowledge, albeit implicitly, that there are some issues in times of armed conflict which are not connected to the armed conflict, e.g. people detained for reasons not connected to the armed conflict. ${ }^{88}$ Significantly, the sense of retaining some sort of dividing line between international human rights law and international humanitarian law is also confirmed by the literature that has been reviewed above on governance and everyday life. This literature provides clear indications that armed groups often engage in activities relating to law enforcement in territory under their control, for reasons which are not explicitly linked to the armed conflict.

The literature reviewed in this article confirms that especially in protracted armed conflicts, there are persuasive reasons for retaining a similar dividing line in rebelheld territory between the international humanitarian law framework and the international human rights law framework, as in State-held territory. Indeed, the application of narrower Kunarac-type criteria confirms the view of the drafters of Additional Protocol II that there can be situations within the law enforcement

\footnotetext{
86 The exploration of this idea was inspired by footnote 16 in Melzer (2009), pp. 142-143 where he states that "while the detention of a common thief in the domestic territory of a party to the conflict would hardly justify the application of Article 75 of Additional Protocol I, this situation would change already if that same thief were arrested by an occupying power who is exercising its authority for reasons related to the conflict'.

87 See for example Melzer (2010), p. 43 who advocates that armed groups exercising 'authority or power over persons, objects or territory for reasons related to an armed conflict must comply with the law enforcement paradigm, albeit derived exclusively from international human rights law'.

88 See also Tuck (2011), p. 762, an ICRC employee specialising in detention, who observes that the LTTE in Sri Lanka and the CPN-M in Nepal routinely deprived people of their liberty for reasons related, and unrelated, to the armed conflict.
} 
framework in which individuals are arrested, detained and prosecuted in areas under rebel control for reasons that can legitimately be said to be unconnected to the armed conflict. Significantly, it also leaves room for the acknowledgement that it is too simplistic to say that an armed group's exercise of that authority is always connected to the military goals of the group. In situations where the exercise of authority is found to be unconnected to the group's military strategy, any mistreatment by members of an armed group during trial or detention will not constitute a war crime, but instead may be characterised as a human rights violation. Yet importantly, it also leaves scope for the recognition that there are some armed groups, like IS, who seem to deliberately integrate the imposition of appalling conditions of cruelty into their law enforcement activities, as part of their military strategy. ${ }^{89}$ In these cases, the application of the narrower Kunarac criteria would allow an armed group's brutal approach to the suppression of ordinary crime to be identified as violations of international humanitarian law and war crimes.

\section{Conclusions}

In conclusion, it has been shown that there is significant normative merit to the practice of applying human rights norms to armed groups. While clearly there remains work to be done on how it can be best operationalised, the article has identified that the value of human rights law can be particularly profound within the law enforcement paradigm, where armed groups are exercising control over persons or territory for protracted periods. Indeed, this article has shown that the identification of the 'life goes on driver' is key to understanding the value of human rights law within that paradigm. For when one thinks of armed conflict situations, it may be tempting to imagine that rights such as the freedom of movement, the right to work or protection from common crime will be displaced by more pressing considerations of physical security and survival. But when one examines the empirical research from social science literature, one realises that this is often not the case. Moreover, it is noteworthy that while international humanitarian law provides crucial protections to victims of armed conflict, it also reproduces a narrative of non-international armed conflict where individuals are portrayed as being either fighters or civilians. It replicates a top-down analysis of armed conflict, whose starting point is the identification of the parties. While this is a fundamentally important perspective, the article has shown that human rights law, which places the individual in the centre of its framework, is well placed to provide a complementary perspective. It is able to respond to new research emerging from political science and anthropology which emphasises the multidimensional experiences of armed conflict, in which individuals are not only victims but also participants in the social fabric of life, with a full measure of agency.

Open Access This article is distributed under the terms of the Creative Commons Attribution 4.0 International License (http://creativecommons.org/licenses/by/4.0/), which permits unrestricted use,

\footnotetext{
${ }^{89}$ International Commission of Inquiry on the Syrian Arabic Republic, 'Rule of Terror: Living under ISIS in Syria', 14 November 2014, see for example paras. 20, 30.
} 
distribution, and reproduction in any medium, provided you give appropriate credit to the original author(s) and the source, provide a link to the Creative Commons license, and indicate if changes were made.

\section{References}

Aeschlimann A (2005) Protection of detainees: ICRC action behind bars. Int Rev Red Cross 857:83-122 Al-Tamimi A (2015) The evolution in Islamic State administration: the documentary evidence. Perspect Terror 9(4):117-129. http://www.terrorismanalysts.com/pt/index.php/pot/article/view/447/html. Accessed July 2016

Arjona A (2015) Civilian resistance to rebel governance. In: Arjona A, Kasfir N, Mampilly Z (eds) Rebel governance in civil war. Cambridge University Press, Cambridge, pp 180-201

Arjona A, Kasfir N, Mampilly Z (2015) Introduction. In: Arjona A, Kasfir N, Mampilly Z (eds) Rebel governance in civil war. Cambridge University Press, Cambridge, pp 1-20

Barter S (2015) The rebel state in society: governance and accommodation in Aceh, Indonesia. In: Arjona A, Kasfir N, Mampilly Z (eds) Rebel governance in civil war. Cambridge University Press, Cambridge, pp 226-245

Bothe B et al (1982) New rules for victims of armed conflicts: commentary on the two 1977 protocols additional to the Geneva Conventions of 1949. Martinus Nijhoff, The Hague

Casalin D (2011) Taking prisoners: reviewing the international humanitarian law grounds for deprivation of liberty by armed opposition groups. Int Rev Red Cross 883:743-782

Clapham A (2006) Human rights obligations of non-state actors. Oxford University Press, Oxford

Constantinides A (2010) Human rights obligations and accountability of armed opposition groups: the practice of the UN Security Council. Hum Rights Int Legal Discourse 4:89-110

Ellsberg D (2003) Secrets: a memoir of Vietnam and the Pentagon Papers. Penguin, New York

Gaggioli G (2014) Sexual violence in armed conflicts: a violation of international humanitarian law and human rights law. Int Rev Red Cross 894:503-538

Gill $\mathrm{T}$ (2013) Some thoughts on the relationship between international humanitarian law and international human rights law: a plea for mutual respect and a common sense approach. In: Haeck Y et al (eds) The realisation of human rights when theory meets practice: studies in honour of Leo Zwaak. Intersentia, Antwerp, pp 335-350

Henckaerts J-M, Doswald Beck L (2005) Customary international humanitarian law. Cambridge University Press, Cambridge

Hessbruegge $\mathbf{J}$ (2005) Human rights violations arising from conduct of non-state actors. Buffalo Hum Rights Law Rev 11:21-88

Hill-Cawthorne L (2015) Humanitarian law, human rights law and the bifurcation of armed conflict. ICLQ 64:293-325

ICRC (1987) Commentary on the Additional Protocols of 8 June 1977 to the Geneva Conventions of 12 December 1949. Martinus Nijhoff, Dordrecht

Kalyvas S (2009) The logic of violence in civil war. Cambridge University Press, Cambridge

Kasfir N (2015) Rebel governance-constructing a field of inquiry: definitions, scope, patterns, order, causes. In: Arjona A, Kasfir N, Mampilly Z (eds) Rebel governance in civil war. Cambridge University Press, Cambridge, pp 21-46

Kilcullen D (2010) Counterinsurgency. Hurst \& Co Publishers Limited, London

Kolomba Beck T (2012) The normality of civil war: armed groups and everyday life in Angola. Campus, Frankfurt

Lubkemann SC (2010) Culture in chaos: a social anthropology of the social condition of war. University of Chicago Press, Chicago

Mampilly Z (2011) Rebel rulers: insurgent governance and civilian life during war. Cornell University Press, Ithaca

McCorquodale R, La Forgia R (2001) Taking off the blindfolds: torture by non-state actors. Hum Rights Law Rev 1:189-218

Melzer N (2009) Targeted killing in international law. Oxford University Press, Oxford

Melzer N (2010) Law enforcement and the conduct of hostilities. In: Gill T, Fleck D (eds) The handbook of the international law of military operations. Oxford University Press, Oxford, pp 33-49 
Meron T (1983) On the inadequate reach of humanitarian and human rights law and the need for a new instrument. AJIL 77:589-606

Moir L (2002) The law of internal armed conflict. Cambridge University Press, Cambridge

Rodenhauser T (2012) Human rights obligations of non-state armed groups in other situations of violence: the Syria example. Int Humanit Legal Stud 3:263-290

Rodley R (1993) Can armed opposition groups violate human rights? In: Mahoney KE, Mahoney P (eds) Human rights in the twenty-first century. Martinus Nijhoff, Dordrecht, pp 297-318

Rosenau J (1992) Governance, order and change in world politics. In: Rosenau J, Czempiel E (eds) Governance without government: order and change in world politics. Cambridge University Press, Cambridge, pp 1-29

Ruys T (2007) Crossing the thin blue line: an inquiry into Israel's recourse to self-defence against Hezbollah. Stanf J Int Law 42:265-294

Ryngaert C (2008) Human rights obligations of armed groups. Revue belge de droit international 41:355-381

Sassòli M (2011) The role of human rights and international humanitarian law in new types of armed conflict. In: Ben-Naftali O (ed) International humanitarian law and international human rights law. Oxford University Press, Oxford, pp 34-94

Sassòli M, Olson L (2008) The relationship between international humanitarian and human rights law where it matters: admissible killing and internment of fighters in non-international armed conflicts. Int Rev Red Cross 871:599-627

Sivakumaran S (2005) Torture in international human rights and international humanitarian law. Leiden J Int Law 18:541-556

Sivakumaran S (2009) Courts of armed opposition groups: fair trials or summary justice? J Int Crim Justice 7:489-513

Sivakumaran S (2014) International humanitarian law. In: Moeckli D, Shah S, Sivakumaran S (eds) International human rights law. Oxford University Press, Oxford, pp 479-495

Tilly C (2003) The politics of collective violence. Cambridge University Press, Cambridge

Tuck D (2011) Detention by armed groups: overcoming challenges to humanitarian action. Int Rev Red Cross 883:759-782

Van der Wilt H (2012) War crimes and the requirement of a nexus with an armed conflict. J Int Crim Justice 10:1113-1128

Verhoeven H (2009) The self-fulfilling prophecy of failed states: Somalia, state collapse and the global war on terror. J East Afr Stud 3:405-425

Weinstein J (2007) Inside rebellion: the politics of insurgent violence. Cambridge University Press, Cambridge

Zegveld L (2002) The accountability of armed opposition groups in international law. Cambridge University Press, Cambridge

Katharine Fortin is Assistant Professor at Utrecht University, teaching human rights law, international humanitarian law and public international law. She is the founder and co-author of the Armed Groups and International Law blog and her forthcoming monograph on armed groups and human rights law will be published by Oxford University Press in 2017. She gives thanks to the editors of this journal for their valuable comments on a previous version of this article and to Rogier Bartels for his comments. 